\title{
Al-Qadisiyah Journal of Pure Science
}

\author{
ISSN(Printed): 1997-2490ＩSSN(Online): $2411-3514$
}

DOI : /10.29350/jops.

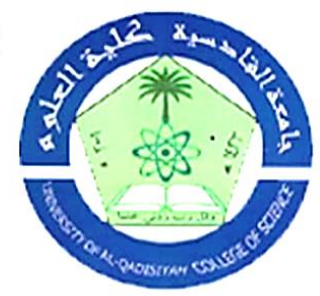

\section{Quantitative structure-activity relationship studies of series of chalcones derivatives as inhibitors of tumor necrosis factor-alpha}

\section{Authors Names \\ a. Wisam A. Radhi \\ b. Sadiq M. H. Ismael, \\ c. Jasim M. Al-Shawi}

\section{Article History}

Received on: $4 / 5 / 2020$

Revised on: $19 / 5 / 2020$

Accepted on: 10/6/2020

Keywords:

QSAR

chalcones derivatives

tumor necrosis

DOI:https://doi.org/10.29350/ jops.2020.25. 3.1129
ABSTRACT

Quantitative structure-activity relationship (QSAR) teqnique was used to predict the biological activity of a series of chalcones compounds as antiinflammatory. 26 physicochemical descriptors are tested in QSAR equations configuration to predict biological effectiveness of compounds under study. The geometries of the compounds under investigation were initially optimized at level (PM3) in accordance to the semi-empirical theory, and subsequently through the B3LYP procedure at the 6-31G(d) basis set in accordance to the DFT theory. The values of correlation coefficients $\left(\mathrm{R}^{2}\right)$ in Eqs (1-3) ranged from $0.794-0.873$, the Fisher ratios $(F)$ values ranged from 14.161-26.206 and the standard errors (S) values ranged from 0.262-0.334. The results demonstrated good models based on Eq.3, along with high of $\mathrm{R}^{2}$, $\mathrm{F}$ and minimum $\mathrm{S}$ by employing three parameters $r(\mathrm{C} 3-\mathrm{C} 5)$, (LUMO+1) and $($ LUMO+2). This signifies that these parameters play a significant role in determining anti-inflammatory characteristics.

MSC: 30C45, 30C50

\section{Introduction}

Chalcone is regarded as a key class of natural product that is broadly distributed in vegetables, fruits, soya-based foodstuff, spices and tea. Its pharmacological activities have recently garnered much interest [1]. Chalcones, or 1,3- diaryl-2-propen-1-ones, fall under the flavonoid family. Chemically, they are made up from open-chain flavonoids, in which a three-carbon $\alpha, \beta$ unsaturated carbonyl system joins the two aromatic rings. The most commonly occurring chalcones in nature are usually polyhydroxylated in the aryl rings. Many chalcones' phenolic groups possess radical quenching properties and have gained popularity in using the chalcones rich plant extract or the compounds as food preservatives or drugs [2].

Quantitative structure-activity relationship (QSAR) defines how a difference can occur in a known biological activity in terms of a function of molecular descriptors that have been derived

a Department of Chemistry, Polymer research Center, University of Basrah, Basrah, Iraq, E-Mail: wisam.radhi@uobasrah.edu.iq

b Department of Chemistry, College of Education for Pure Science, University of Basrah, Basrah, Iraq E-Mail: $\underline{\text { sadiq.ismael.si. }}$ $@$ @gmail.com,ja

${ }^{c}$ Department of Chemistry, College of Education for Pure Science, University of Basrah, Basrah, Iraq E-Mai jasim alshawi@yahoo.com 
based on the chemical structure pertaining to a set of molecules. Many physiological activities associated with a molecule could be linked with their structure as well as composition. Molecular descriptors, also referred to as numerical depictions pertaining to the molecular structures, are employed to perform QSAR analysis [3]. QSAR studies generally involve two steps: first, descriptors (physical-chemical parameters) are generated which encode for chemical structural information; and second, a statistical regression method correlates changes in structure with changes in chemical properties or biological activity [4].

Recently, many efforts have been made to employ QSAR models in medical-chemistry with a focus on robust models to allow easy prediction of different biological activates, ease practical efforts and optimise certain lead candidates with chemical entities like designing of chemicals in terms of Orl1 receptor antagonists. This also includes subjecting 24 of the imidazole derivatives on QSAR [5], designing enzyme and hormone inhibitors that are more effective[6-8], enhancing antifungal and antibacterial activities for certain predicted chemicals [9-11], developing QSAR models pertaining to specific steroidal derivatives that have been presented as being antiinflammatory agents [12] as well as considerable anti-cancer activates [13]. In the previous year, QSAR models were evaluated for anti-tubercular activity to fight against M. tuberculosis as well as anticancer agents to fight with hepatic cancer cell lines, HepG2 [14,15]. This work aims to evaluate QSAR on 15 chalcones derivatives as inhibiting LPS-induced TNP-a production that possess potent antioxidant characteristics.

\section{Theory:}

The electronegativity, $\chi$ and hardness $\eta$ can be defined as below [16]:

$\chi=\frac{1}{2}(I+A)$

$\eta=1 / 2(I-A)$

$I=-\varepsilon H O M O \quad$ and $A=-\varepsilon L U M O$

Here, A and I signify electron affinity and ionisation potential, respectively, for the molecule. HOMO represented the energy of Highest Occupied Molecular Orbital; LUMO represented the energy of Lowest Unoccupied Molecular Orbital. The chemical potential pertaining to cation and anion could be described as follows [17]:

$\mu^{-}=-1 / 4(3 I+A)$

$\mu^{+}=-1 / 4(I+3 A)$

$\mu=-(I+A) / 2$

\section{Experimental}

\section{Modelling and Geometry Optimisation}

15 chalcones derivatives were considered to carry out quantum chemical calculations. The semi-empirical PM3 method pertaining to the Hyperchem program 8.0 (www.hyper.com) was employed to get the final geometries. The B3LYP method was employed with the 6-31G(d) basis set that was used in the PCgamess program, and further single point calculations were done for the obtained optimised geometries [18]. The inhibition of LPS-induced TNP- $\alpha$ production by 15 compounds that were studied was all taken from the reference [19]. Fig. 1 displays the structures of 15 compounds. 
<smiles>COc1cccc(/C=C/C(=O)c2c(OC)cc(OC)c(Br)c2O)c1</smiles>

$4 a$<smiles>COc1cc(/C=C/C(=O)c2c(OC)cc(OC)c(Br)c2O)cc(OC)c1</smiles>

$4 \mathrm{c}$<smiles>COc1cc(OC)c(C(=O)/C=C/c2ccc(C#N)c(Cl)c2)c(O)c1Br</smiles>

$4 \mathrm{e}$<smiles>COc1cc(OC)c(C(=O)/C=C/c2cccc(Cl)c2)c(O)c1Br</smiles>

$4 \mathrm{~g}$<smiles>COc1ccc(OC)c(/C=C/C(=O)c2c(OC)cc(OC)c(Br)c2O)c1</smiles>

$4 b$<smiles>COc1cc(OC)c(C(=O)/C=C/c2ccc(F)cc2)c(O)c1Br</smiles>

$4 d$<smiles>COc1cc(OC)c(C(=O)/C=C/c2ccc(Br)cc2)c(O)c1Br</smiles>

$4 f$<smiles>COc1cc(OC)c(C(=O)/C=C/c2cc(Cl)cc(Cl)c2)c(O)c1Br</smiles> 
<smiles>COc1cc(OC)c(C(=O)/C=C/c2cccc(Cl)c2)c(O)c1Br</smiles>

$4 \mathrm{i}$<smiles>COc1cc(OC)c(C(=O)/C=C/c2ccccc2)c(O)c1Br</smiles>

$4 \mathrm{k}$<smiles>COc1ccc(/C=C/C(=O)c2c(OC)cc(OC)c(Br)c2O)c(OC)c1</smiles>

$4 n$<smiles>COc1cc(OC)c(C(=O)/C=C/c2ccc(Cl)cc2)c(O)c1Br</smiles>

$4 j$<smiles>COc1cc(OC)c(C(=O)/C=C/c2ccc([N+](=O)[O-])cc2)c(O)c1Br</smiles>

$4 \mathrm{~m}$<smiles>COc1cc(OC)c(C(=O)/C=C/c2cccc(N)c2)c(O)c1Br</smiles>

40<smiles>COc1cc(OC)c(C(=O)/C=C/c2ccc([N+](=O)[O-])c(Cl)c2)c(O)c1Br</smiles> 


\section{Results and Discussion:}

The theoretical molecular descriptors proceeds have been derived from the compounds' chemical structure. Table 1 lists out the set of prepared molecules. For each type, three QSAR models were generated; overall, wherein 3 models would represent 15 chalcones derivatives as well parametrically depicted Eqs. 1-3 along with correlation coefficient $\left(\mathrm{R}^{2}=0.794-0.873\right)$. It is already known that a high predictive ability could be achieved when the MLR model possesses low standard error (S), high $\mathrm{R}^{2}$ and Fisher ratio (F) values and the minimum number of descriptors $[20,21]$.

The first model relied on just three descriptors, $\left(Q_{c 5}\right),\left(Q_{B r}\right)[21]$ and $(\mu-)$, which were found to be a good model, wherein the correlation coefficient $\mathrm{R}^{2}$ values were found to be 0.794 , as Eq. 1 .

$\mathrm{pIC}_{50}=9.918\left(\mathrm{Q}_{\mathrm{c}}\right)-54.782\left(\mathrm{Q}_{\mathrm{Br}}\right)-2.169\left(\mu^{-}\right)+3.288$

The obtained equation's statistical features:

$$
\mathrm{R}^{2}=0.794, \mathrm{Ra}^{\wedge} 2=0.738, \mathrm{~S}=0.334, \mathrm{~F}=14.161, \mathrm{Q}^{2}=0.796
$$

Fig 2. Present the relationships between experimental $\mathrm{pIC}_{50}$ and predicted $\mathrm{pIC}_{50}$ by Eq 1 .

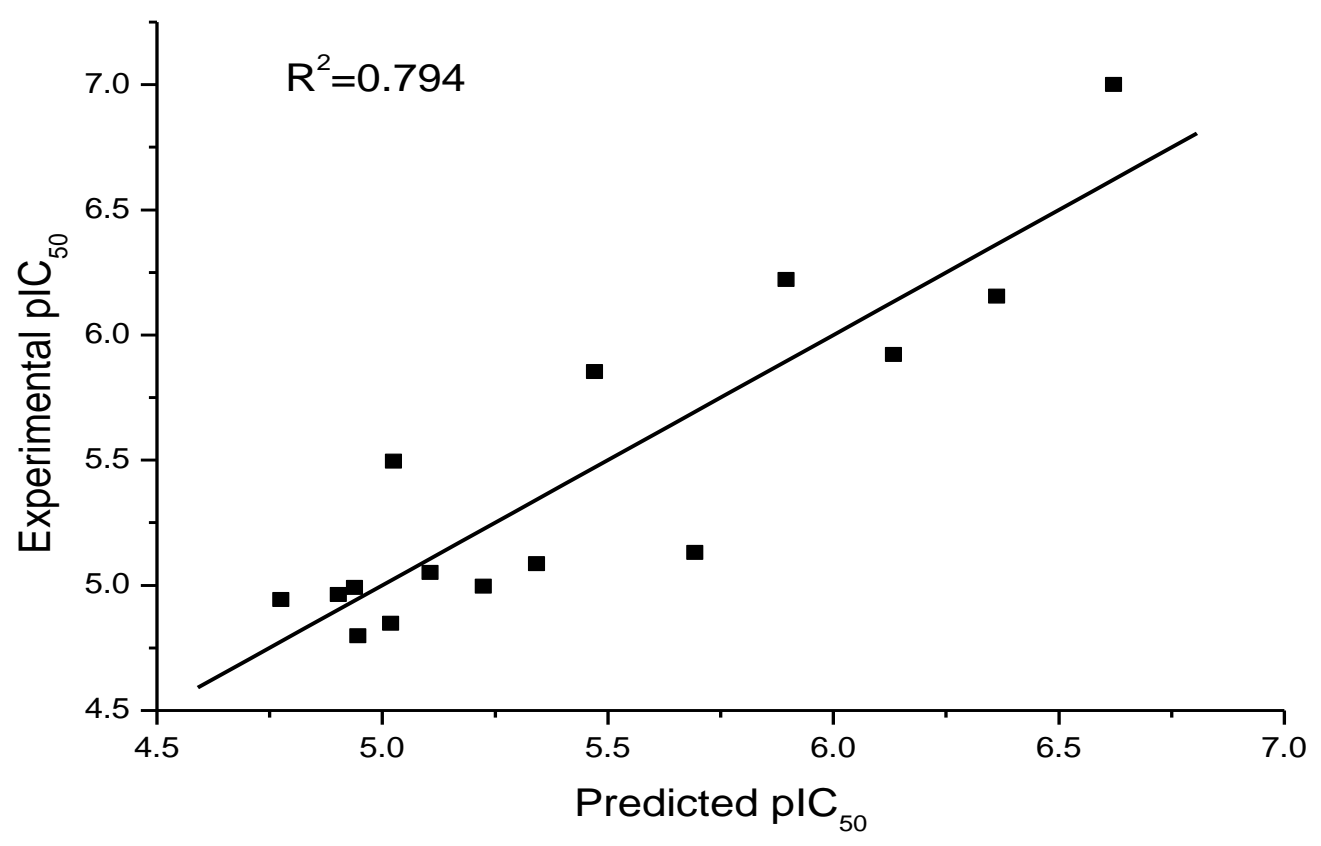

Fig. 2 shows the relationship between the experimental pIC $\mathrm{pl}_{50}$ data and predicted $\mathrm{pIC}_{50}$ by this model 1 


\begin{tabular}{|c|c|c|c|c|c|c|c|c|c|c|c|c|c|}
\hline Comp. & $\mu$ & \multicolumn{11}{|c|}{ Table 1. Descriptors as the independent variables used for QSAR analysis of } & QBr \\
\hline $4 \mathrm{a}$ & -3.657 & -2.7045 & -4.6095 & 0.103 & 1.465 & 5.562 & 1.752 & 3.657 & 3.81 & -5.562 & -1.752 & $\begin{array}{c}124.05 \\
2\end{array}$ & 0.157308 \\
\hline $4 \mathrm{~b}$ & -3.4445 & -2.56825 & -4.32075 & 0.037 & 1.473 & 5.197 & 1.692 & 3.4445 & 3.505 & -5.197 & -1.692 & $\begin{array}{c}123.36 \\
9\end{array}$ & 0.148331 \\
\hline $4 \mathrm{c}$ & -3.4405 & -2.50925 & -4.37175 & 0.071 & 1.464 & 5.303 & 1.578 & 3.4405 & 3.725 & -5.303 & -1.578 & 123.76 & 0.155762 \\
\hline $4 d$ & -4.193 & -3.162 & -5.224 & 0.035 & 1.469 & 6.255 & 2.131 & 4.193 & 4.124 & -6.255 & -2.131 & $\begin{array}{c}123.88 \\
3\end{array}$ & 0.16132 \\
\hline
\end{tabular}


Wisam A. Radhi, Sadiq M. H. Ismael , Jasim M. Al-Shawi. Al-Qadisiyah Journal of Pure Science 25,3 (2020) pp. Chem. 1-14

\begin{tabular}{|c|c|c|c|c|c|c|c|c|c|c|c|c|c|}
\hline $4 \mathrm{e}$ & -4.204 & -3.1155 & -5.2925 & 0.069 & 1.476 & 6.381 & 2.027 & 4.204 & 4.354 & -6.381 & -2.027 & $\begin{array}{c}123.21 \\
9\end{array}$ & 0.166109 \\
\hline $4 \mathrm{f}$ & -3.959 & -2.9195 & -4.9985 & 0.094 & 1.472 & 6.038 & 1.88 & 3.959 & 4.158 & -6.038 & -1.88 & $\begin{array}{c}122.89 \\
4\end{array}$ & 0.17749 \\
\hline $4 \mathrm{~g}$ & -3.9585 & -2.89325 & -5.02375 & 0.069 & 1.493 & 6.089 & 1.828 & 3.9585 & 4.261 & -6.089 & -1.828 & $\begin{array}{c}123.01 \\
3\end{array}$ & 0.181339 \\
\hline $4 \mathrm{~h}$ & -4.129 & -3.078 & -5.18 & 0.074 & 1.494 & 6.231 & 2.027 & 4.129 & 4.204 & -6.231 & -2.027 & $\begin{array}{c}122.87 \\
5\end{array}$ & 0.185489 \\
\hline $4 \mathrm{i}$ & -4.0715 & -3.05025 & -5.09275 & 0.099 & 1.471 & 6.114 & 2.029 & 4.0715 & 4.085 & -6.114 & -2.029 & $\begin{array}{c}123.45 \\
3\end{array}$ & 0.179761 \\
\hline $4 \mathrm{j}$ & -4.187 & -3.157 & -5.217 & 0.058 & 1.48 & 6.247 & 2.127 & 4.187 & 4.12 & -6.247 & -2.127 & $\begin{array}{c}123.04 \\
3\end{array}$ & 0.185387 \\
\hline $4 \mathrm{k}$ & -4.2855 & -3.25025 & -5.32075 & 0.095 & 1.466 & 6.356 & 2.215 & 4.2855 & 4.141 & -6.356 & -2.215 & $\begin{array}{c}123.80 \\
8\end{array}$ & 0.167155 \\
\hline $4 \mathrm{~m}$ & -4.106 & -2.9905 & -5.2215 & 0.072 & 1.473 & 6.337 & 1.875 & 4.106 & 4.462 & -6.337 & -1.875 & $\begin{array}{c}122.51 \\
5\end{array}$ & 0.184552 \\
\hline $4 n$ & -4.0595 & -3.38075 & -4.73825 & 0.077 & 1.475 & 5.417 & 2.702 & 4.0595 & 2.715 & -5.417 & -2.702 & $\begin{array}{c}122.85 \\
2\end{array}$ & 0.174444 \\
\hline 40 & -3.526 & -2.545 & -4.507 & 0.087 & 1.442 & 5.488 & 1.564 & 3.526 & 3.924 & -5.488 & -1.564 & $\begin{array}{c}125.67 \\
7\end{array}$ & 0.146784 \\
\hline $4 p$ & -3.917 & -2.67 & -5.164 & 0.082 & 1.473 & 6.411 & 1.423 & 3.917 & 4.988 & -6.411 & -1.423 & $\begin{array}{c}122.17 \\
3\end{array}$ & 0.187728 \\
\hline
\end{tabular}

\section{Table 1.Continued}

\begin{tabular}{|c|c|c|c|c|c|c|c|c|c|c|c|c|c|}
\hline Comp. & LUMO+1 & LUMO+2 & $\omega-$ & $\omega+$ & $\Delta \omega-+$ & $r(\mathrm{C}=\mathrm{C})$ & $r(\mathrm{O}-\mathrm{H})$ & $r(\mathrm{C}-\mathrm{Br})$ & $r(\mathrm{C}=0)$ & $\eta(\mathrm{ev})$ & QC2 & Q04 & QC3 \\
\hline $4 a$ & -0.634 & -0.161 & 5.5767691 & 1.9197691 & 7.4965382 & 1.362 & 0.981 & 1.947 & 1.250 & 1.905 & -0.12884 & -0.42072 & -0.1404 \\
\hline $4 \mathrm{~b}$ & -0.715 & -0.195 & 5.3263568 & 1.8818568 & 7.2082136 & 1.355 & 0.98 & 1.95 & 1.248 & 1.7525 & -0.08182 & -0.38685 & -0.13735 \\
\hline $4 \mathrm{c}$ & -0.531 & -0.078 & 5.1307914 & 1.6902914 & 6.8210829 & 1.361 & 0.981 & 1.946 & 1.251 & 1.8625 & -0.13228 & -0.41544 & -0.10374 \\
\hline $4 \mathrm{~d}$ & -0.789 & -0.571 & 6.6174045 & 2.4244045 & 9.0418089 & 1.358 & 0.981 & 1.949 & 1.251 & 2.062 & -0.12589 & -0.41619 & -0.14786 \\
\hline $4 \mathrm{f}$ & -0.448 & -0.174 & 6.0088991 & 2.0498991 & 8.0587981 & 1.354 & 0.981 & 1.935 & 1.246 & 2.079 & $\begin{array}{l}-0.12798 \\
\end{array}$ & -0.39921 & -0.14062 \\
\hline
\end{tabular}




\begin{tabular}{|c|c|c|c|c|c|c|c|c|c|c|c|c|c|}
\hline $4 \mathrm{~g}$ & -0.514 & -0.462 & 5.9230378 & 1.9645378 & 7.8875756 & 1.355 & 0.982 & 1.937 & 1.246 & 2.1305 & -0.11485 & -0.41733 & 0.079286 \\
\hline $4 \mathrm{~h}$ & -0.813 & -0.726 & 6.382588 & 2.253588 & 8.636176 & 1.355 & 0.982 & 1.936 & 1.245 & 2.102 & -0.11542 & -0.41373 & 0.079548 \\
\hline $4 \mathrm{i}$ & -0.473 & -0.285 & 6.3491071 & 2.2776071 & 8.6267142 & 1.357 & 0.981 & 1.937 & 1.249 & 2.0425 & -0.11913 & -0.41177 & -0.14559 \\
\hline $4 j$ & -0.991 & -0.65 & 6.6060896 & 2.4190896 & 9.0251791 & 1.357 & 0.981 & 1.935 & 1.247 & 2.06 & -0.14904 & -0.41962 & 0.10377 \\
\hline $4 \mathrm{k}$ & -0.742 & -0.631 & 6.8366048 & 2.5511048 & 9.3877096 & 1.36 & 0.982 & 1.944 & 1.251 & 2.0705 & -0.12644 & -0.41832 & -0.14629 \\
\hline $4 n$ & -0.296 & -0.027 & 8.2692497 & 4.2097497 & 12.478999 & 1.353 & 0.981 & 1.936 & 1.245 & 1.3575 & -0.12573 & -0.39495 & -0.14523 \\
\hline 40 & -0.454 & -0.048 & 5.176618 & 1.650618 & 6.827236 & 1.364 & 0.98 & 1.95 & 1.253 & 1.962 & -0.11902 & -0.43295 & -0.13239 \\
\hline $4 p$ & -2.356 & -0.897 & 5.3462101 & 1.4292101 & 6.7754202 & 1.355 & 0.982 & 1.936 & 1.25 & 2.494 & -0.12285 & -0.412 & -0.14404 \\
\hline
\end{tabular}

Definition of Descriptors Used in This Study: $\mu=$ Chemical potential,$\mu^{+}=$Chemical potential for cation, $\mu=$ Chemical potential for anion, $Q_{c 5}$ : Charge of C5 atom , r(C3-C5):Length bond between two carbon atoms three and five , I= ionization potential, $A=$ electron affinity, $\chi=$ Electronegative, E.Gap =Different between HOMO and LUMO is energy gaps in eV, HOMO=The energy of Highest Occupied Molecular Orbital in eV, LUMO= The energy of Lowest Unoccupied Molecular Orbital in eV , qBr: Charge of brome atome, $r(C-B r)$ :Length bond between carbon atome and brome atome, $\omega-=$ Electro donating, $\omega+=$ Electro accepting, $\Delta \omega-+=$ Electro accepting relative to the electro donating power, $r(C=C)$ : Length bond between carbon atome and carbon atome, $r(\mathrm{O}-\mathrm{H})$ :Length bond between oxygen atome and hydorogen atome, $r(C=0)$ : Length bond between carbon atome and oxygen atome, $\eta$ : hardness, $Q_{c 3}:$ Charge of $C 3$ atom, $Q_{c 2}:$ Charge of $C 2$ atom, Qo4: Charge of $\mathrm{O} 4$ atom

In the first eq. 1 presented above, the negative value associated with the charge of bromide and chemical potential ( $\mu-)$ signifies that there is a decrease in the activity with rise in the charges values for bromide and chemical potential $(\mu-)$ of the chalcones. On the other hand, positive values pertaining to charge of C5 as well as imply that there is a rise in activity with increase. The charge of atoms is responsible for the biological activity effects was reported in the literatures $[22,23]$.

While in eq. 2 , there were three descriptors, and a very good correlation coefficient $\mathrm{R}^{2}$ could be established when the descriptor $\mathrm{Q}_{\mathrm{C} 5}$ was substituted with $L$ (04-C1-C2). Decrease in standard error could be observed when compared with Eq. 1. In this model, the activity of the chalcones was found to increase with the decrease in the charge of bromide as well as chemical potential $(\mu-)$. In contrast, if there is an increase in angle (O4-C1-C2), it will increase the activity as well. 
$\mathrm{pIC}_{50}=0.444 L(04-\mathrm{C} 1-\mathrm{C} 2)-26.493\left(\mathrm{Q}_{\mathrm{Br}}\right)-1.873\left(\mu^{-}\right)-54.151$

The obtained equation's statistical properties:

$\mathrm{R}^{2}=0.816, \mathrm{Ra}^{\wedge} 2=0.765, \mathrm{~S}=0.316, \mathrm{~F}=16.215, \mathrm{Q}^{2}=0.818$

Fig. 3 depicts the relationship existing between the predicted $\mathrm{pIC}_{50}$ via this model 2 and the experimental $\mathrm{pIC}_{50}$ data.

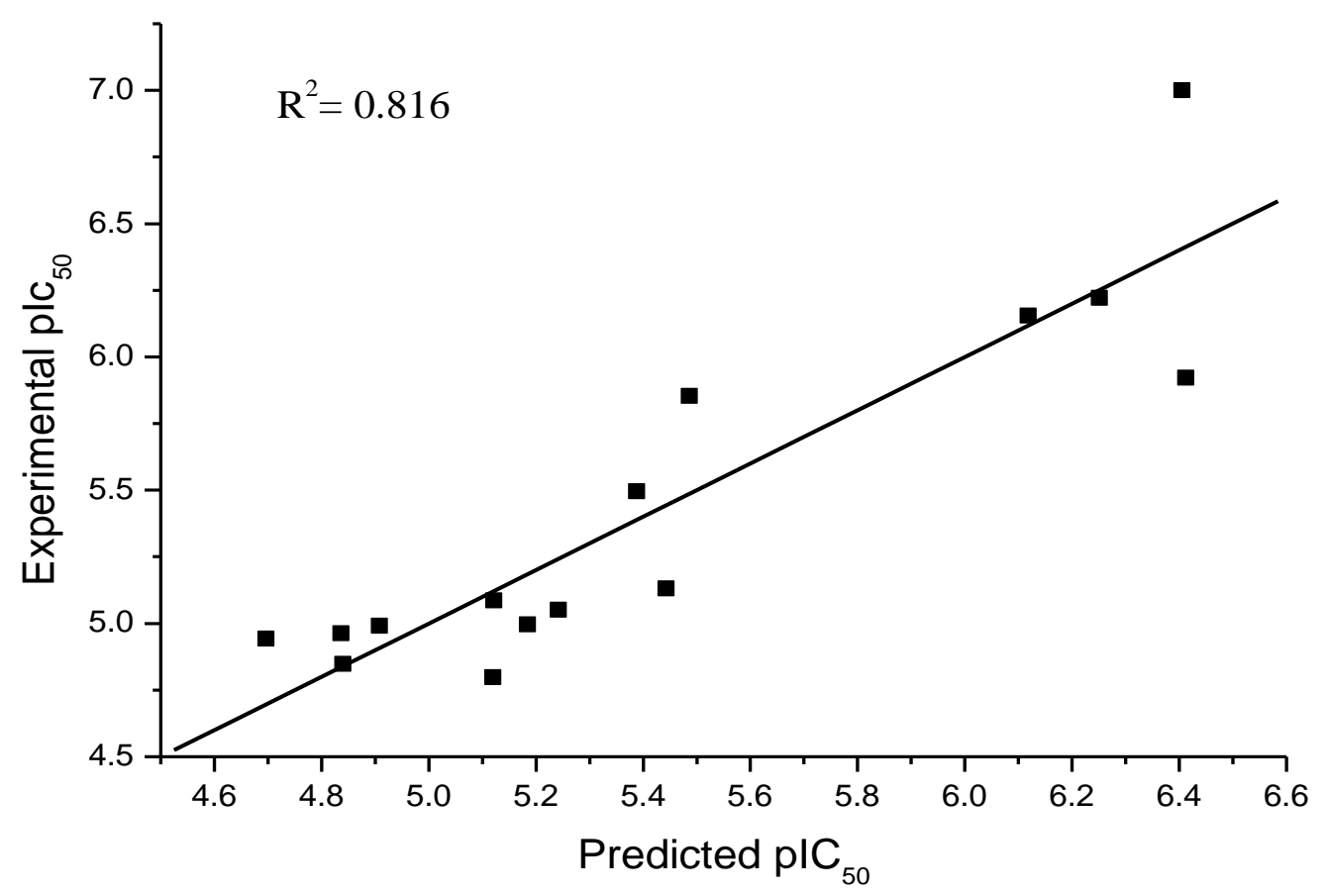

Fig.3, show the relationship between the experimental $\mathrm{pIC}_{50}$ data and predicted $\mathrm{pIC}_{50}$ by this model.2

In Eq. 3, three descriptors (LUMO+1), (LUMO+2) were employed and $r$ (C3-C5). This yielded the decrease standard error and increase correlation coefficient and the sequential Fischer test (F). The bond length, bond angle and LUMO molecular orbitals were applied to predict the biological activity [24].

$\mathrm{pIC}_{50}=1.190(\mathrm{LUMO}+1)-3.149($ LUMO+2) $-54.204 r(\mathrm{C} 3-\mathrm{C} 5)+84.939$

The obtained equation's statistical properties:

$\mathrm{R}^{2}=0.873, \mathrm{Ra}^{\wedge} 2=0.838, \mathrm{~S}=0.262, \mathrm{~F}=26.206, \mathrm{Q}^{2}=0.876$

Fig. 4 depicts the relationship existing between the predicted $\mathrm{pIC}_{50}$ via this model 3 and the experimental $\mathrm{pIC}_{50}$ data. 


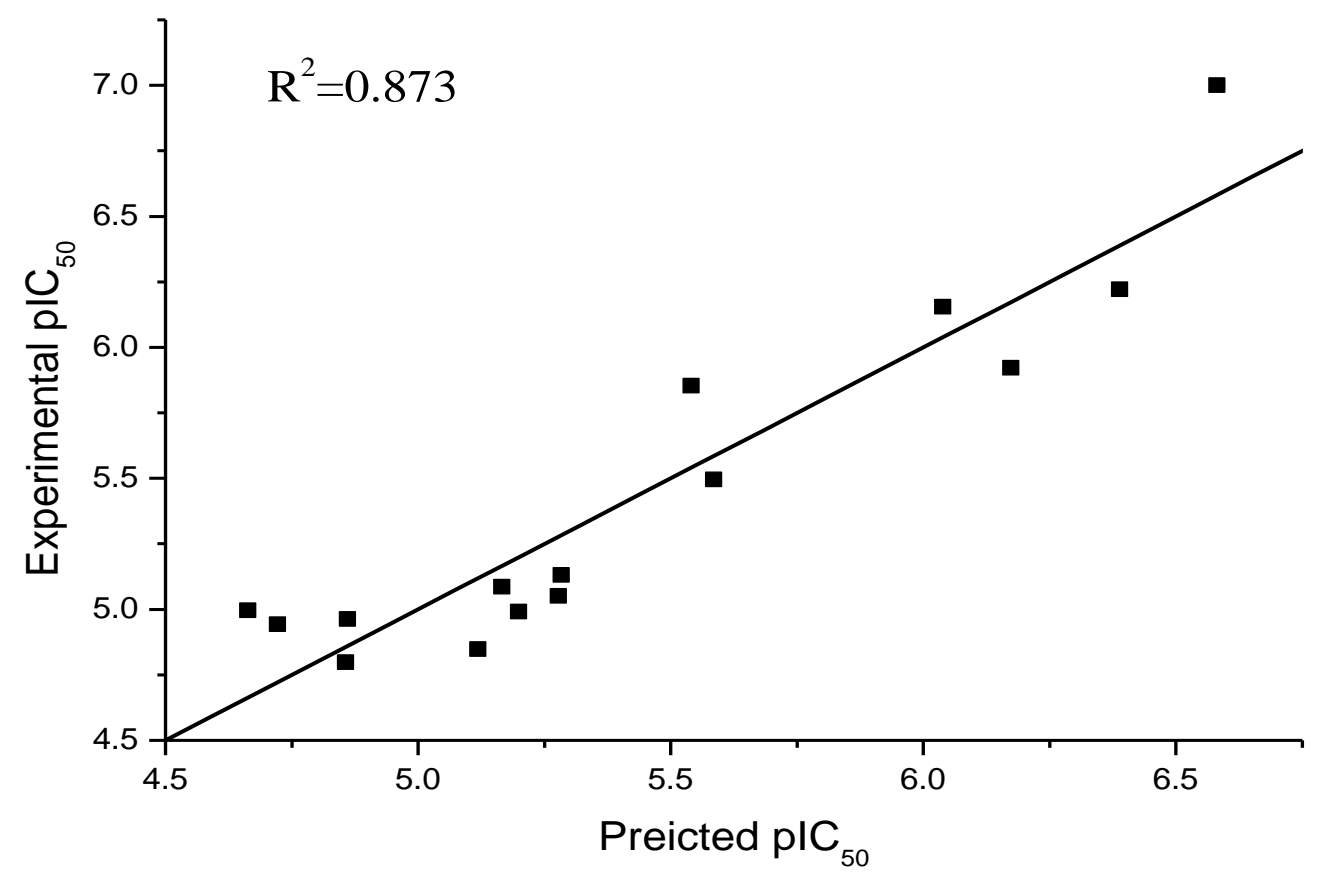

Fig.4, show the relationship between the experimental $\mathrm{pIC}_{50}$ data and predicted $\mathrm{pIC}_{50}$ by this model.3

Table 2 displays the variance inflation factors pertaining to descriptors employed in Eqs. 1, 2 and 3. In all equations, the VIF pertaining to the descriptors $\left(\mathrm{Q}_{\mathrm{c}}\right),(\mathrm{Q} \mathrm{Br}), \mu, L$ (O4-C1-C2), (LUMO+1), (LUMO+2) and $r$ (C3-C5) were fairly large.

Table 2. The varied inflation factor (VIF) quantifies the severity of multicollinearity least squares regression analysis. 


\begin{tabular}{|c|c|c|c|}
\hline Descriptor & Eq.1 & Eq. 2 & Eq.3 \\
\hline$Q_{c 5}$ & 3.454 & - & - \\
\hline $\mathrm{Q}_{\mathrm{Br}}$ & 3.187 & 4.511 & - \\
\hline$\mu^{-}$ & 2.405 & 2.159 & - \\
\hline$L(\mathrm{O} 4-\mathrm{C} 1-\mathrm{C} 2)$ & - & 2.809 & \\
\hline $\mathrm{HOMO}+1$ & - & - & 2.501 \\
\hline $\mathrm{HOMO}+2$ & - & - & 3.196 \\
\hline $\mathrm{r}(\mathrm{C} 3-\mathrm{C} 5)$ & & - & 1.517 \\
\hline
\end{tabular}

\section{Conclusions}

The calculated parameters based on Quantum chemical could be successfully employed in deriving and designing QSAR that can predict activity values of series of chalcones as antiinflammatory. The study signified that modelling of the predicted anti-inflammatory for compounds under study could be done based on multiple linear regression (MLR). The good equation was derived based on twenty six parameters. The model was found to rely on Eq. 3. The best produced model is the MLR model that has a good statistical fit as clear from $\operatorname{Ra}^{\wedge} 2=0.838$, $\mathrm{R}^{2}=0.873, \mathrm{~S}=0.262$, and $\mathrm{F}=26.206$. 


\section{References}

[1]. G. D. Carlo, N. Mascolo, A.A. Izzo and F. Capasso, Flavonoids: old and new aspects of a class natural therapeutic drugs, Life Sci.,(65)(1999),337-353.

[2]. D.N. Dhar, The chemistry of chalcones and related compounds. Wiley, New York.. (1981), 213-312.

[3]. S.Ikeno, C. Ogino, T. Ito, and N. Shimizu, Detection of benzene derivatives by recombinant E. coli with Ps promoter and GFP as a reporter protein, Biochemical engineering journal, 15(3) (2003),193-197.

[4]. M. A Jalal , Z .T. Almalki and W. A.Radhi , Quantitative Structure-Activity Relationship Studies Of Amino Acids Conjugated 2-Amnio-Arylthiazole As Antifungal, Journal of Physics: Conf. Series,(1294)(2019),1-11.

[5]. A. K. Srivastava, N. Shukla, Quantitative structure activity relationship (QSAR) studies on a series of imidazole derivatives as novel ORL1 receptor antagonists, Journal of Saudi Chemical Society, 17(3)(2013), 321-328.

[6]. P. Prathipati, G. Pandey and A. K. Saxena, CoMFA and Docking Studies on Glycogen Phosphorylase a Inhibitors as Antidiabetic Agents. Journal of Chemical Information and Modeling, 45(1) (2005), 45-136.

[7]. O. A. Donini and P. A. Kollman, Calculation and Prediction of Binding Free Energies for the Matrix Metalloproteinases, Journal of Medicinal Chemistry, 43(22)(2000), 4180-4188.

[8]. J. Xu, S. Huang, H. Luo, G. Li, J. Bao, Sh. Cai and Y. Wang, QSAR Studies on Andrographolide Derivatives as $\alpha$-Glucosidase Inhibitors, International Journal of Molecular Sciences, (11)(2010), 880-895.

[9]. S. G. R. Mota, T. F. Barros and M. S. Castilho, 2D QSAR Studies on a Series of Bifonazole Derivatives with Antifungal Activity, Journal of the Brazilian Chemical Society, 20(3)(2009), 451459.

[10]. T. T. Talele and V.M. Kulkarni, Three-Dimensional Quantitative Structure-Activity Relationship (QSAR) and Receptor Mapping of Cytochrome P-450 ${ }_{14 \alpha \mathrm{DM}}$ Inhibiting Azole Antifungal Agents, Journal of Chemical Information and Computer Sciences, 39(2)(1999), 204210.

[11]. H. Ji, W. Zhang, M. Zhang, Y. Zhou, M. Zhang, J. Zhu, Y. Song, J. Lu, and J.Zhu, A ThreeDimensional Model of Lanosterol 14 $\alpha$-Demethylase of Candida albicans and Its Interaction with 
Azole Antifungals", Journal of Medicinal Chemistry, 43(13)(2000), 2493-2505.

[12]. S. Dubey and P. Piplani , QSAR Studies of Some Synthetic Structurally Related Androstene Derivatives as Anti-Inflammatory Agents, Chemical informatics journal, 1(2)(2015),1-5.

[13]. K. A. Hussain, W. A-H. Radhi, and S. M.H. Ismael, Quantitative Structure-Activity Relationships (QSAR) study and improving it of some schiff-base ligands as anticancer for prostate cancer, Journal of Chemical and Pharmaceutical Research, 4(3)(2012), 1702-1707.

[14]. K. A. Hussain, S. M. H. Ismael and W. A. Radhi , Quantitative Structure-activity relationships (QSAR) and Docking Studies on Pyrimidine Derivatives for Antitubercular Activity against M. tuberculosis H37Rv,British Journal of Pharmaceutical Research,13(1)(2016),1-11.

[15]. W. A. Radhi , S.M.H. Ismael, J. M. Al-Shawi and K. A.Hussein, Quantitative Structure-Activity Relationship Studies of Flavonoids Substituted as Anticancer Agents Activity against the Growth of the Hepatic Cancer Cell lines HepG2, International Journal of Chemistry,9(2)(2017),1-9.

[16]. R.G. Pearson, Absolute electronegative and hardness correlated with molecular orbital theory,Pro.Nat.Acad.Sci.USA,83(22)(1986),8440-8441.

[17]. J. L. Ga'zquez, A. Cedillo and A. Vela, Electrodonating and Electroaccepting Powers, J. Phys. Chem. A,111(10)(2007),1966-1970.

[18]. Granovsky A. A. Granovsky, Firefly version 8, www http://classic.chem.msu.su/gran/firefly/index.html.

[19]. B. P. Bandgar, B. S. Hote, N. A. Dhole and R. N. Gacche, Synthesis and biological evaluation of novel series of chalcone derivatives as inhibitors of cyclooxygenase and LPS-induced TNF- $\alpha$ with potent antioxidant properties, Med Chem Res, (21)(2012),2292-2299.

[20]. R. B. Darlington, Regression and Linear Models, McGraw-Hill, New York, (1990).

[21]. D. L. Massart, B. G. Vandeginste, L. M. Buydens, S. D. Jong, P. J. Lewi, and J. Smeyers-Verbeke, "Handbook of Chemometrics and Qualimetrics: Part A", , Elsevier, Amsterdam, (1997).

[22]. W. A. Radhi, S. M. H Ismael., J. M. Al-Shawi and K. A. Hussain,Quantitative structure-activity relationship (QSAR) investigation on 2-arylideneaminobenzimidazole derivatives as antiproliferative activity against mv4-11 human leukaemia cells,Mediterranean Journal of Chemistry,9(2)(2019),95-101.

[23]. R. S. Elias, S.M-H. Ismael and B. A. Saeed ,Quantum Chemical QSAR Study of 1-phenyl- 
X- benzimidazoles as Inhibitors of PDGFR Tyrosin Kinase,Int.J. PharmTech Res. 3(4)(2011), 2183-2189.

[24]. B.A Saeed, R.S.Elias, S M-H. Ismael and K. A. Hussain, Theoretically Predicted Descriptors Based,Quantitative Structure Activity Relationship Study ofthe Activity of Acridines Against B-16 Melanoma,Am. J. Applied Sci., 8 (8) (2011), 773-776. 